\title{
Digital dømmekraft er et tema du bør diskutere med dine kolleger
}

Digitale vennskap mellom sykepleiere og pasienter eller pårørende kan viske ut grensen mellom det å være profesjonell og privat.

\section{Kristin Haugen}

Medlem av Rådet for sykepleieetikk og universitetslektor/ph.d.-stipendiat

Norges teknisk-naturvitenskapelige universitet, Gjøvik

\section{Håkon Johansen}

Medlem av Rådet for sykepleieetikk og geriatrisk sykepleier

Sosiale medier

Digital dømmekraft

Sykepleien 2019107 (77356) (e-77356)

DOI: 10.4220/Sykepleiens.2019.77356

Reiduns ektefelle, Karstein, ble rammet av hjerneslag bare

48 år gammel. Nå er han pasient på sykehjemmets

langtidsavdeling. Han har mistet evnen til å uttrykke seg

muntlig og skriftlig. 
Reidun er ufør etter lengre perioder med depresjon de siste årene. Hun bor like ved sykehjemmet og besøker Karstein daglig. Hun fär scerlig god kontakt med Ellen, som er ektefellens primcersykepleier. De har lange samtaler om situasjonen til Karstein og om livet generelt. Ellen merker at Reidun blir lettere og gladere når de snakker sammen.

En kveld sender Reidun en venneforespørsel til Ellen på Facebook. Ellen tenker at det var da hyggelig, og aksepterer.

En liten motforestilling melder seg om at hun kanskje burde voere forsiktig, at hun nå krysser en grense over til noe som er mer privat enn profesjonelt. Hun vet også at det er delte meninger $i$ avdelingen om bruk av sosiale medier $i$ jobbsammenheng, og hun har jo selv reagert på kollegers likes, delinger og kommentarer.

\section{Sykepleier i sosiale medier}

Ifølge en unders $\varnothing$ kelse som Tidsskriftet Sykepleien foretok i 2012 (1), er ikke sykepleier Ellen alene om å kjenne på dilemmaer i sosiale medier knyttet til taushetsplikt, ytringsfrihet, pårørende, pasienter og kollegers anvendelse. I en unders $\varnothing$ kelse blant 300 sykepleiere svarte en av tre at de opptrer både som privatperson og som sykepleier i sosiale medier. En av ti mente at det var greit å være venner med pasientene sine på Facebook.

Resultatene skapte debatt i 2012, og det var delte meninger. Rådet for sykepleieetikk erfarer at det fortsatt er behov for å holde refleksjonen varm, og har tatt initiativ til at digital dømmekraft inkluderes i NSFs yrkesetiske retningslinjer (YER) (2) når disse revideres høsten 2019.

Begrepet digital dømmekraft beskrives som evnen til å vurdere andres og egne handlinger på nettet, evnen til å finne og vurdere relevant informasjon og vår kompetanse om ulike digitale verktøy (3). Digital dømmekraft handler om vår evne til kritisk refleksjon ved bruk av digitale medier knyttet til blant annet personvern, nettvett og opphavsrett (4). 


\section{Digitale dilemmaer}

Rådet mottar stadig flere henvendelser knyttet til dilemmaer som sykepleiere opplever i møte med sosiale medier. Disse samsvarer med resultater i unders $\varnothing$ kelsen, og vi kjenner dem også igjen hos Kvalnes, som har gjort en studie av dilemmaer som kan oppstå for brukere av sosiale medier (5).

Kvalnes peker på noen viktige problemstillinger: Hvem er jeg i sosiale medier? Kvalitetssikrer jeg informasjon som potensielt kan spre seg raskt og effektivt? Hva er konsekvensene av våre ambisjoner om følgere og likes? I hvilken grad kan jeg bruke sosiale medier til å ytre meg? Hvilke utfordringer kan oppstå som et resultat av ulik forståelse og kunnskap blant dem som anvender sosiale medier?

Ellen møter Reidun som før $i$ avdelingen. De har sine samtaler og deler innlegg på hver sine sider på Facebook eller melder hverandre gjennom chatten. Hyggelig dette, tenker Ellen, og merker at hun fortsatt bidrar til å lyse opp litt $i$ Reiduns vanskelige hverdag.

Etter hvert blir det likevel utfordrende for Ellen. Reidun poster innlegg og sender meldinger på chat ofte. Hun er ganske så åpen og personlig $i$ innleggene om seg selv og Karstein. Ellen synes Reidun burde holde igjen og ikke voere så personlig, scerlig ikke når hun skriver om ektefellen, som ikke kan gi uttrykk for hva han mener.

Men Ellen synes det er vanskelig à si ifra til Reidun. Det blir også vanskelig for Ellen å kommentere bilder og tekst om Karstein. Han er jo hennes pasient, og hun har taushetsplikt. Hun spør seg etter hvert om Facebook er egnet for en slik kontakt, og får mer og mer lyst til à begrense utvekslingene med Reidun på nettet.

\section{Samfunnets tillit, fagets omdømme}


Sosiale medier kan gi gode muligheter til å møte pasienter og brukere der de er, som for eksempel Helsesista, som sprer informasjon og bryter tabuer. Facebook er et delvis lukket medium, men det kan også nå langt. Informasjonen her er vesentlig mer offentlig enn den fortrolige samtalen mellom pårørende og sykepleier.

Helsedirektoratet (6) og Helsetilsynet (7) er skeptiske når et sykepleier-pasient/pårørende-forhold utvikler seg til vennskap, fordi grensen mellom profesjonell og privat kan bli uklar.

I utøvelsen av sykepleie er vi avhengige av pasientens og samfunnets tillit. Ifølge YER skal sykepleiere verne om fagets omdømme. Når Ellen svarer på eller gir likes til Reiduns åpenhjertige poster på Facebook, og Karstein ikke har mulighet til å gi noen motreaksjoner, trues både hans verdighet og rett til vern om fortrolige opplysninger. Det vil trolig mange reagere negativt på, og en slik bruk av sosiale medier kan bidra til å svekke vårt omdømme.

\section{Refleksjon i forkant}

Kun halvparten av sykepleierne i unders $\varnothing$ kelsen fra 2012 svarte at de har drøftet med arbeidsgiver hvordan de bør fremstå i og bruke sosiale medier. Rådet $\varnothing$ nsker å stimulere til refleksjon om bruk av sosiale medier på arbeidsplassen. Digital dømmekraft er absolutt et tema som vi bør diskutere med våre kolleger. Vi er bedre rustet til å møte etiske utfordringer dersom vi på forhånd reflekterer over de dilemmaene som vi kan møte på.

Hvordan er det på din arbeidsplass? Reflekterer dere over digital dømmekraft? Hvilke dilemmaer har du og dine kolleger opplevd i møte med sosiale medier?

\section{Referanser}

1. Helmers AKB. OK å dele

jobbhverdagen på sosiale medier? Tidsskriftet

Sykepleien. 2012;100(12):20. 
2. Norsk Sykepleierforbund. Yrkesetiske retningslinjer for sykepleiere. Oslo: NSF. Tilgjengelig fra: https://www.nsf.no/visartikkel/2193841/17102/Yrkesetiske-retningslinjer (nedlastet 14.06.2019).

3. Michaelsen AS. Det digitale klasserommet. Utnytt mulighetene! Oslo: Cappelen Damm Akademisk; 2015.

4. $\quad$ Engen BK, Giæver TH, Mifsud L. Digital dømmekraft. Oslo: Gyldendal Akademisk; 2017.

5. $\quad$ Kvalnes $\varnothing$. Etikk i sosiale medier. I: Brandtzæg PB, Gillund L, Krokan A, Kvalnes $\varnothing$, Meling AT, Wessel-Aas J, red. Sosiale medier i all offentlighet: lytte, dele, delta. Oslo: Kommuneforlaget; 2012.

6. Aftenposten. Helsedirektoratet skeptisk til sykepleiere på Facebook. Aftenposten. 24. oktober 2012. Tilgjengelig fra: https://www.aftenposten.no/norge/i/vQV2w/Helsedirek toratet-skeptisk-til-sykepleiere-pa-Facebook (nedlastet 14.06.2019).

7. Helsetilsynet. Kommunikasjon på sosiale medium - rolleforståinga til helsepersonell og kravet til teieplikt. Tilsynsmeldingen. Oslo; Helsetilsynet: 2017. 